\title{
https://doi.org/10.48009/1_iis_2005_346-352 \\ IMPLEMENTING AN NSF-FUNDED SCHOLARSHIP PROGRAM
}

\author{
Dr. Lynn R. Heinrichs, Elon University, lheinrichs@elon.edu \\ Dr. David J. Powell, Elon University, dpowell2@elon.edu
}

\begin{abstract}
The paper describes the implementation of a scholarship program to attract computer science and computer information systems majors. The scholarships are funded through the National Science Foundation Computer Science, Engineering, and Mathematics, Scholarship (CSEMS) Program. Funds were awarded from NSF for ten, four-year scholarships. Scholarships are available to students with academic promise and financial need. The paper describes the development of the NSF proposal, the recruitment and selection process for scholarship students, and the current status of the program.
\end{abstract}

Keywords: Computer majors, scholarships, enrollment, NSF, grant, funding

\section{INTRODUCTION}

After the year 2000 and the dot-com bust, many computer science and computer information systems programs suffered a downturn in majors. There are numerous ways to address the problem of declining enrollments such as increased marketing and new course offerings. In this paper, the authors describe the implementation of a scholarship program enabled by a National Science Foundation grant to attract students to the computing sciences. The paper describes the background of the problem, the NSF program supporting the grants, the recruitment and selection process, and the current status of students in the program.

\section{BACKGROUND OF PROBLEM}

Most faculty members need only look as far as their own classrooms to witness a decline in the number of students choosing a computer career. According to a Taulbee Survey [11], the number of new undergraduates in computer science/computer engineering dropped by a significant $23 \%$ from 2002-2003. Kessler [4] reported similar patterns at selected institutions. And, while it is easy to focus on the recruiting aspect of undergraduate enrollment, Cohoon and Chen [2] point out that retention is also part of the problem. Examining enrollment data from 1994-1999, when the average number of majors in computer science was "rising dramatically," the CS attrition rate averaged $16 \%$.

Foley [3] identified one of three challenges for the computing research community as attracting "the very best undergraduate and graduate students to meet the projected labor-force needs of the next decade [p.1]." The list of problems cited that must be overcome include, but are not limited to the following:

- Short-term job losses caused by the dot-com crash,

- Budget cuts arising from declining enrollments,

- The perception of computing as a dead-end career due to off-shoring, 
- The misconception that programming is a solitary activity,

- Small numbers of women and minorities.

This is not the first time the computer field has experienced declining majors in undergraduate programs. Authors of the late 1980s and early 1990s remind us all too well that low enrollments are cyclical $[5,8]$. In a paper entitled, "The Implications of Declining Enrollments in Undergraduate CIS Programs in the United States," Cale, Mawhinney, and Callaghan [1] wrote:

During the past decade, fewer and fewer college students have been electing to major in the fields of science, technology, and mathematics in higher education in the United States. Many explanations are offered for this trend ... In a world where technological leadership seems inextricably linked with economic leadership, the declining interest in technical fields could have a severe and negative impact in financial, social, and political spheres [pp. 167-168].

The 1991 paper concludes with the following recommendations for recruiting more majors and increasing the retention rate: (1) enhance the service course through faculty staffing and use of professionals and managers as guest speakers and (2) promote the major by changing course titles as well as incorporating more business and communication skills [pp, 179-180].

Other academics have suggested additional remedies for attracting new students to the discipline. Williams and Heinrichs [9] proposed (1) writing a letter of recognition and encouragement to all students with B grades in the introductory MIS service course, (2) designing a marketing brochure for prospective high schools students, and (3) developing a first-class, multi-media presentation for use at open houses. Wooley [10] advocated using the computing lab itself as a recruitment tool.

The current authors are faculty members in the computing sciences department at a private university in the southeast. The department offers two majors: computer science and computer information systems. While the computer science degree is well-established, the computer information systems program has only been available since Fall 2002.

The first signs of downward enrollments in both the CS and CIS programs occurred about Fall 2003. A drop off in computer science majors was evident from Fall 2002 to Fall 2003 (see Table 1). The decline was in part attributed to the new CIS major. However, other warning signs accompanied the enrollment slip. The number of prospective students at open houses indicating an interest in a computer major declined. Additionally, the number of students enrolled in the introductory courses in each program dropped. In light of national reports indicating similar trends at other institutions, the department examined possible tactics to reverse the situation.

Table 1. CIS and CS Major Enrollments

\begin{tabular}{lcccc}
\multicolumn{1}{c}{ Major } & F2000 & F2001 & F2002 & F2003 \\
\hline Computer Information Systems & NA & NA & 9 & 36 \\
Computer Science & 81 & 80 & 56 & 41 \\
Total Majors & 81 & 80 & 65 & 77
\end{tabular}




\section{THE NATIONAL SCIENCE FOUNDATION PROPOSAL}

In response to the declining enrollment warnings and the growing need for scholarship funds, the authors developed a proposal for the National Science Foundation's Computer Science, Engineering, and Mathematics Scholarship (CSEMS) Program [6]. The program "supports scholarships for academically talented, financially needy students, enabling them to enter the high technology workforce following completion of an associate, baccalaureate, or graduate level degree in computer science, computer technology, engineering, engineering technology, or mathematics [p.1]. Qualified students can receive up to $\$ 3,125$ for four years, depending upon the institution's proposal. Students receiving awards under CSEMS must demonstrate financial need as defined by the U.S. Department of Education. The definition of "academically talented" is left up to the proposing institution.

\section{Program Objectives}

The following objectives were identified for the proposed scholarship program, internally referred to as NSFCS (National Science Foundation Computing Sciences):

1. Increase the number of academically talented students with unmet financial need who choose a major in the computing sciences.

2. Increase the proportion of women majors in the institution's computing sciences programs.

3. Successfully retain students to degree completion through academic and social support systems.

4. Prepare students for transition to employment or graduate school through participation in experiential learning activities.

The investigators believed that the institution and department were well-positioned for trying to increase the number of women majoring in computing sciences. First, $63 \%$ of the university's undergraduate population is female, providing a large pool of women from which to recruit new majors. Second, six of the eight faculty members teaching CS or CIS majors are women. Students have numerous opportunities to observe female role models through advising, classes, and student organization activities.

\section{Program Elements}

The institution already has many program elements in place that were instrumental in supporting the objectives of the NSFCS proposal. These elements, summarized in Table 2, include the freshman seminar, peer tutoring, an ACM student chapter, and an experiential learning requirement (ELR). The NSFCS scholarship proposal incorporated the four elements in the following ways:

- Scholarship students would enroll as a cohort in the freshman seminar class.

- Additional funds to support peer tutoring would be included in the NSF budget.

- Funds to support student membership in the ACM chapter would be included in the budget submitted to NSF. 
- A letter of support from a local non-for-profit organization to provide internships for scholarship students would be included in the NSF proposal.

Table 2. Program Elements in Support of Objectives

\begin{tabular}{lcccc} 
& $\begin{array}{c}\text { Freshman } \\
\text { Seminar }\end{array}$ & $\begin{array}{c}\text { Peer } \\
\text { Tutoring }\end{array}$ & $\begin{array}{c}\text { ACM } \\
\text { Chapter }\end{array}$ & $\begin{array}{c}\text { Experiential } \\
\text { Learning } \\
\text { Requirement }\end{array}$ \\
\hline Achieving academic success & $\mathrm{X}$ & $\mathrm{X}$ & & $\mathrm{X}$ \\
Developing a support network & $\mathrm{X}$ & $\mathrm{X}$ & $\mathrm{X}$ & $\mathrm{X}$ \\
Preparing for a career & & & $\mathrm{X}$ &
\end{tabular}

The NSF proposal also borrowed some program ideas from existing fellows programs at the university. Fellows are selective, four-year programs which offer talented students exciting advantages such as special courses, guaranteed internships, faculty mentoring, and fellows scholarships. Programs are established for honors, arts and sciences, teaching, business, leadership, and journalism and communications. The Fellows played a key role in the NSFCS curricular elements, the scholarship selection criteria, the application process, and the scholarship administration process. Scholarship application, selection, and administration are discussed later in this document.

\section{Number of Scholarships}

To determine the total number of scholarships to request, the investigators looked at the current makeup of incoming students eligible for federal financial aid. Table 3 shows the comparative numbers for all university students and those declaring an interest in CIS or CS for the 2003-04 academic year. Of the 1227 of enrolled freshmen, about $36 \%$ met financial eligibility requirements. Twenty-two students indicated an interest in CS or CIS; of those, only four met financial eligibility requirements, about half the percentage of freshmen overall. The average need for students at the university was $\$ 15,668$ of which $\$ 6,776$ was met.

Table 3. Students and Financial Need for Fall 2003

\begin{tabular}{lccc} 
& $\begin{array}{c}\text { Total No. of } \\
\text { Students }\end{array}$ & $\begin{array}{c}\text { Total Eligible for } \\
\text { Financial Aid }\end{array}$ & \% of Students \\
\hline All Freshmen & 1227 & 438 & $36 \%$ \\
Freshmen interested in CS/CIS & 22 & 4 & $18 \%$
\end{tabular}

Given that only about one-third of incoming students were eligible for financial aid, the investigators were concerned about requesting support for too many scholarships. The investigators consulted with the university's sponsored programs representative and researched past award proposals. The final decision to request funds for ten scholarships seemed bold but reachable.

\section{RECRUITMENT AND SELECTION}

The original plan put forward in the proposal was for recruitment and selection of recipients to take place before the Fall 2004 semester began. However, this assumed that recruitment 
activities could begin by July 1 . Formal notification of the grant award was received about the second week of July 2004. Because of vacations and other summer events, the recruitment and selection process was delayed another week, pushing the schedule very close to the opening of the fall semester.

The department could have waited until the fall semester was underway to recruit 10 qualified freshmen from the entering class. However, after discussions with the Financial Aid office, "sooner rather than later" seemed to be the overriding message with respect to identifying recipients. The recruitment plan identified in the NSF proposal was put into action immediately as follows:

- Send letters of personal invitation to all freshmen eligible for federal financial aid with a 3.0 GPA or better.

- Publish a scholarship Web page with additional information about the scholarship program and a scholarship application.

- Allow three weeks for students to complete applications and one week to review them by departmental faculty members.

- Notify students via regular mail and e-mail before freshman move-in day.

To expedite work, existing documents for similar scholarship and award programs were used with appropriate editing. The application form was a modified version of that used by the Arts and Sciences Fellows program. Scholarship details were cut and pasted from contracts for similar scholarships. The department worked diligently with the offices on campus to ensure any distributed materials met university standards.

The investigators relied primarily on the personal letters of invitation to publicize the scholarship opportunity. Additionally, the university's news bureau issued a press release that received coverage in several local papers. A feature story was also published on the university's news page with links to the scholarship Web page.

With the assistance of the financial aid and admissions offices, 356 letters were sent to selected students meeting the 3.0 GPA and aid eligibility criteria. Much to the investigator's surprise, 18 applications were received. Unfortunately, only 4 of the 18 (22\%) were female, although applications were evenly divided between CS and CIS students. A profile of applicants is contained in Table 4.

Table 4. Profile of Applicants

\begin{tabular}{lr} 
Attribute & Value \\
\hline Intended Major & 9 CS and 9 CIS \\
Average HS GPA & 3.745 \\
Average SAT-Math* & 599 \\
Average SAT-Verbal* & 571 \\
$* 17$ of 18 applicants submitted SAT scores; one submitted ACT
\end{tabular}

The full-time faculty of the department acted as a selection committee of the whole. Faculty reviewed the scholarship applications and met to select the final 10 applicants. The first part of the application provided information on academic achievements, extra-curricular activities, 
employment, and leadership experiences. In part two, applicants were also asked to write a brief essay about why they were interested in a CS or CIS major. Since many of the students had similar profiles, the essays were extremely important in arriving at a final decision on the awardees.

The faculty selected six CS and four CIS majors for the scholarships. Of the ten, only two were female (20\%). The students were notified of the award by mail and e-mail just prior to freshman move-in day. Students individually met with the scholarship director to review the scholarship requirements and sign an agreement.

\section{THE FIRST YEAR EXPERIENCE AND BEYOND}

Scholarship students currently are completing their first year at the university. One of the CIS students withdrew from the university at the end of the first semester for financial reasons; the student transferred to a local state university. Another CIS student was nominated and selected to receive the award.

During the first year, students accepting the scholarship were advised to take at least one computer and one math course appropriate for the major. The faculty believed this demonstrated commitment to the program without an official declaration of major. Students planning to major in computer science were advised to take the first programming course (Java) and calculus. Students planning a CIS major could take statistics or applied calculus for math and MIS or VB for their first computer course.

One of the challenges as students move from freshman to sophomore year will be the declaration of the major. Students entering the university often identify an intended major; however, they cannot officially declare until after completion of their first semester. Students accepting an NSFCS scholarship were not required to declare a major by a specific point in time. The scholarship contract allows students to continue receiving awards as long as they are making progress in the major. The investigators will encourage students to declare their majors during the Spring 2005 semester for several reasons: (1) to formalize their commitment to the program, (2) to assign them a CS or CIS advisor, and (3) to improve the department's count of number of majors.

The scholarship program has proven to be an exciting opportunity for the department. The number of students in the CS and CIS pipeline has increased by ten. The award provided positive publicity both within and outside of the campus community. With the new majors, favorable publicity, and other department achievements, an enrollment rebound appears to be in the making. The spring section of the introductory Visual Basic course more than tripled from 2004 to 2005 .

Will there be other opportunities to apply for CSEMS funds? The following excerpt is taken from the NSF Web site [7]:

From 1999 through 2004, the CSEMS program made grants to colleges and universities to support scholarships for academically talented, financially needy students, enabling 
them to enter the high-technology workforce following completion of an associate, baccalaureate, or graduate-level degree in computer science, computer technology, engineering, engineering technology, or mathematics . . . There are currently over 400 active projects, some of which plan to operate through at least 2008. No proposals are currently being accepted for the CSEMS program, but there likely will be a program solicitation published later in 2005.

The investigators will continue to follow the development of the CSEMS program. When another opportunity arises, serious consideration will be given to applying for additional funding. The CSEMS program has been a success for students, the department, and the institution.

\section{REFERENCES}

1. Cale, E.G., Mawhinney, C.H., \& Callaghan, D.R. (1991 Summer). The Implications of Declining Enrollments in the United States, Journal of Management Information Systems, $8(1), 167-181$.

2. Cohoon, J. M., \& \& Chen, L. (2003 March). Migrating Out of Computer Science, Computing Research News, 15(2), 2-3.

3. Foley, J. (2004 September). Old Challenges, New Opportunities, Computing Research News, $16(4), 1 \& 13$.

4. Kessler, M. (2004 August 8). Fewer College Students Choose Computer Majors, USA Today, retrieved on 2/25/2005 at www.usatoday.com/money/industries/technology/2004-08-08computer-science_x.htm.

5. McBride, W.E., Calhoun, J., Richards, J.L., Taylor, H.G., \& Walters, F.G. (1988). Recruiting More Computer Science Students-What to Do After the "Glamour" Has Gone Away, Proceedings of the $19^{\text {th }}$ SIGSCE Technical Symposium on Computer Science Education, 181.

6. National Science Foundation (2003). Program Solicitation NSF 04-506, Computer Science, Engineering, and Mathematics Scholarships, Directorate for Education and Human

Resources, Division of Undergraduate Education, retrieved on 2/25/2005 at http://www.nsf.gov/publications/pub_summ.jsp?ods_key=nsf04506.

7. National Science Foundation (2005). Web page for the Computer Science, Engineering, and Mathematics Scholarships (CSEMS) Program, Division of Undergraduate Education, retrieved on 2/25/2005 at http://www.nsf.gov/funding/pgm_summ.jsp?pims_id=5257.

8. Smith, (1988). Computing Trends in Small Liberal Arts Colleges, Proceedings of the $19^{\text {th }}$ SIGSCE Technical Symposium on Computer Science Education, 299-303.

9. Williams, G. \& Heinrichs, L. (1995 March). Declining CIS Enrollments: One Institution's Response, Proceedings of the $26^{\text {th }}$ Annual Conference of the Decision Sciences Institute Southwest Region, March 1-4, 10-12.

10. Wooley, B. (2003). Utilizing a Computer Lab to Improve Retention and Recruiting of Computer Science and Computer Information Science Students, Journal of Computing Sciences in Colleges, 18(3), 228-234.

11. Zweben, S. \& Aspray, W. (2004 May). Undergraduate Enrollments Drop; Department Expectations Moderate, Computing Research News, 16(3), 15-19. 